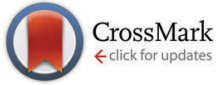

Cite this: Chem. Commun., 2015, 51, 1112

Received 9th October 2014, Accepted 26th November 2014

DOI: $10.1039 / c 4 c c 07999 j$

www.rsc.org/chemcomm

\section{Isoxazole to oxazole: a mild and unexpected transformation $\dagger$}

\author{
Raymond C. F. Jones, ${ }^{\star a}$ Alexander Chatterley, ${ }^{a}$ Romain Marty, ${ }^{a}$ W. Martin Owton ${ }^{b}$ \\ and Mark R. J. Elsegood ${ }^{a}$
}

3-Aryltetrahydrobenzisoxazoles prepared en route to the coleophomone natural products and analogues, were found to undergo a remarkable base-mediated rearrangement to 2-aryltetrahydrobenzoxazoles. The scope of this unprecedented, facile transformation was probed: a range of analogues was produced, a mechanism proposed, and an application demonstrated by synthesis of a known herbicidal compound.

As an extension of our interest in natural products containing the cyclic trione unit $1,{ }^{1,2}$ we were attracted to the coleophomone natural products, exemplified by coleophomones A (2) and B (3), reported as being in equilibrium via an aldol process. ${ }^{3,4}$ This group of metabolites have enzyme inhibitory properties towards bacterial cell wall transglycosylase and human heart chymase. ${ }^{4,5}$

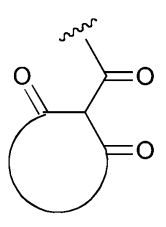

1

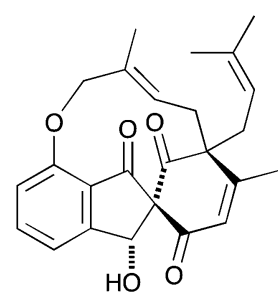

Coleophomone A

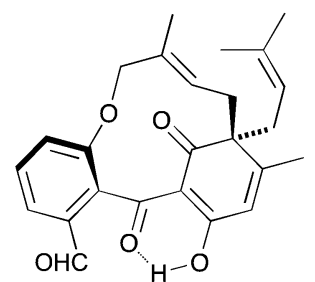

Coleophomone B
Applying our previously reported isoxazole masking strategy for the cyclic trione unit ${ }^{1,2}$ led us to propose the disconnection of Scheme 1, requiring 3-aryltetrahydrobenzisoxazole building blocks to access the natural products and (masked) analogues. Whilst manipulating one such arylbenzisoxazole, we observed a remarkable rearrangement to a 2-arylbenzoxazole. We report here our exploration of this unprecedented, facile transformation.

\footnotetext{
${ }^{a}$ Department of Chemistry, Loughborough University, Leics. LE11 3TU, UK.

E-mail: r.c.f.jones@lboro.ac.uk; Fax: +44 (0)1509 223926;

Tel: +44 (0)1509 222557

${ }^{b}$ Lilly UK, Erl Wood Manor, Windlesham, Surrey, GU20 6PH, UK

$\dagger$ Electronic supplementary information (ESI) available. CCDC 962972-962975. For ESI and crystallographic data in CIF or other electronic format see DOI: $10.1039 / \mathrm{c} 4 \mathrm{cc} 07999 \mathrm{j}$
}

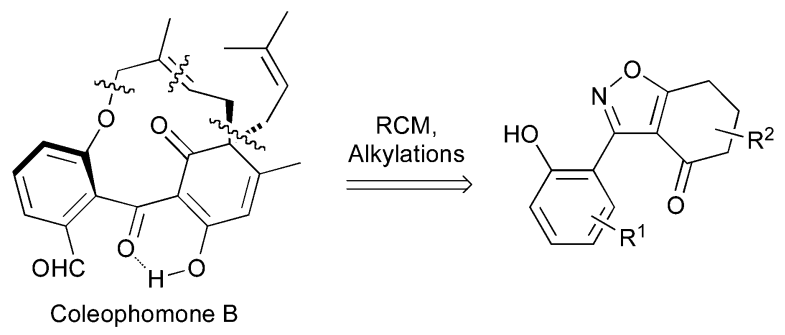

Scheme 1 Strategic disconnection of coleophomones.

A suitable set of 3-aryltetrahydrobenzisoxazoles 4 was prepared by 1,3-dipolar cycloaddition of aryl nitrile oxides [available from benzaldehyde oximes via C-chlorination (NCS, $\mathrm{CHCl}_{3}$ reflux) and 1,3-elimination] with cyclohexane-1,3-diones under basic conditions (Scheme 2). ${ }^{6}$

During attempts to complete $O$-allylation of 3-(2-hydroxyphenyl)benzisoxazole 4a $\left(\mathrm{R}=\mathrm{R}^{1}=\mathrm{H}\right)$ under standard basic conditions $\left(\mathrm{Cs}_{2} \mathrm{CO}_{3}\right.$, THF reflux), we did not observe the expected product but instead isolated 2-(2-allyloxy)tetrahydrobenzoxazole $\mathbf{5}$.

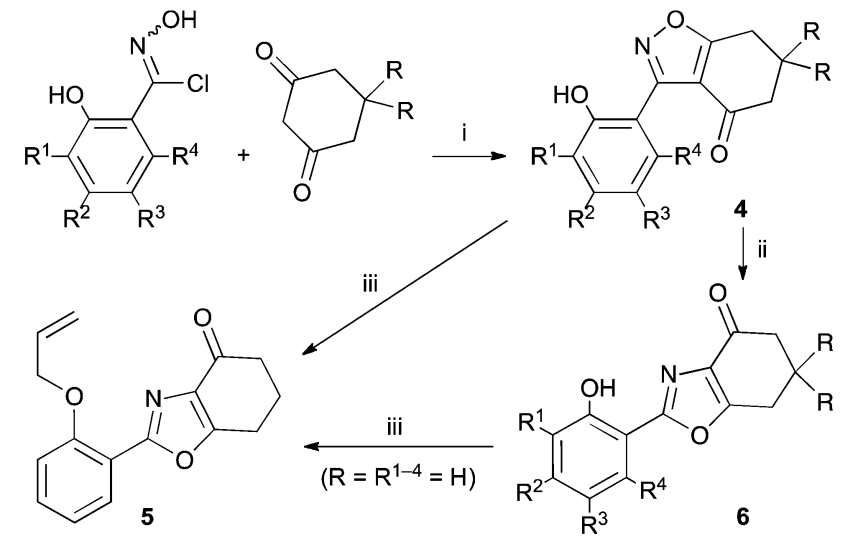

Scheme 2 Synthesis and rearrangement of 3-aryltetrahydrobenzisoxazoles 4. Reagents: (i), $\mathrm{NaOi}-\mathrm{Pr}, \mathrm{i}-\mathrm{PrOH}$; (ii), $\mathrm{Cs}_{2} \mathrm{CO}_{3}$, THF reflux; (iii), $\mathrm{H}_{2} \mathrm{C}=\mathrm{CHCH}_{2} \mathrm{Br}, \mathrm{Cs}_{2} \mathrm{CO}_{3}$, THF reflux. 


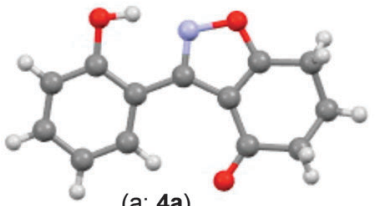

(a: 4a)

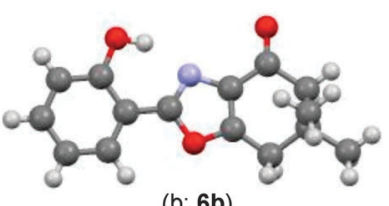

(b; 6b)
Fig. 1 ( $a$ and b) $X$-Ray crystal structures of isoxazole $\mathbf{4 a}$ and oxazole $\mathbf{6 b}$ $(\mathrm{O}=$ red, $\mathrm{N}=$ blue, $\mathrm{C}=$ grey, $\mathrm{H}$ = light grey).

Table 1 Rearrangement of isoxazole $4 a$ to oxazole $\mathbf{6 a}$ under various reaction conditions ${ }^{a}$

\begin{tabular}{|c|c|c|c|}
\hline Entry & Base & Solvent & Yield $^{b}(\%)$ \\
\hline 1 & $\mathrm{Cs}_{2} \mathrm{CO}_{3}$ & THF & 87 \\
\hline 2 & $\mathrm{~K}_{2} \mathrm{CO}_{3}$ & THF & 84 \\
\hline 3 & $\mathrm{Na}_{2} \mathrm{CO}_{3}$ & THF & 5 \\
\hline 4 & $\mathrm{Et}_{3} \mathrm{~N}$ & THF & 0 \\
\hline 5 & DMAP & THF & 0 \\
\hline 6 & DBU & THF & 83 \\
\hline 7 & LDA & THF & 37 \\
\hline 8 & $\mathrm{Cs}_{2} \mathrm{CO}_{3}$ & Toluene & 97 \\
\hline 9 & $\mathrm{NaOi-Pr}$ & i-PrOH & 85 \\
\hline 10 & $\mathrm{Cs}_{2} \mathrm{CO}_{3}$ & $\mathrm{EtOH}-\mathrm{H}_{2} \mathrm{O}$ & 87 (for $7 a)$ \\
\hline 11 & None & $\mathrm{H}_{2} \mathrm{O}$ & 8 \\
\hline 12 & $\mathrm{Cs}_{2} \mathrm{CO}_{3}$ & $\mathrm{H}_{2} \mathrm{O}$ & 91 (for $7 \mathbf{a})$ \\
\hline 13 & $\mathrm{Cs}_{2} \mathrm{CO}_{3} \& \mathrm{EtSH}$ & THF & 6 (for $7 \mathbf{b})$ \\
\hline
\end{tabular}

${ }^{a}$ Isoxazole 1 (2.18 mmol), base $(4.37 \mathrm{mmol})$, reaction time $4 \mathrm{~h}$, solvent under reflux. ${ }^{b}$ Isolated yields refer to 6 a unless otherwise stated.

This rearrangement also took place in the absence of alkylating agent (Scheme 2); the phenolic product $6 \mathbf{a}\left(\mathrm{R}=\mathrm{R}^{1-4}=\mathrm{H}\right)$ was stable to the basic conditions, and was successfully $O$-allylated to give ether 5 on addition of allyl bromide. We have verified the structures of both isoxazole $4 \mathbf{a}$ and dimethyl product oxazole $\mathbf{6 b}\left(\mathrm{R}=\mathrm{Me}, \mathrm{R}^{1-4}=\mathrm{H}\right.$; vide infra) through X-ray crystal structure determinations, Fig. $1 \mathrm{a}$ and $\mathrm{b} . \ddagger$

We further investigated the scope of the remarkable rearrangement of benzisoxazoles 4 to benzoxazoles 6. Using isoxazole $\mathbf{4 a}$, rearrangement was found to occur in aprotic solvents with reaction time of $4 \mathrm{~h}$ under a range of basic conditions (Table 1) including carbonates, alkoxide and amidine, but failed with tertiary amines. In the presence of water or ethanethiol (entries 12, 13) the amide products $\mathbf{7 a , b}$, respectively, of ring opening of the oxazole $\mathbf{6 a}$ were isolated; the constitutions of the amides were confirmed by X-ray crystal structures. ${ }^{7}$

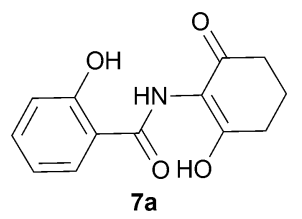<smiles>CCSC1=C(NC(=O)c2ccccc2O)C(=O)CCC1</smiles>

A range of 3-(2-hydroxyphenyl)tetrahydrobenzisoxazoles $\mathbf{4 a - i}$, differently substituted in the aryl and the cyclohexane ring were shown to undergo rearrangement (Table 2) using the convenient $\mathrm{Cs}_{2} \mathrm{CO}_{3}$ conditions (THF reflux) to afford oxazoles $\mathbf{6 a - i . \S}$

We propose the mechanism illustrated in scheme 3 for the rearrangement. Until the oxazole structure was determined, we had supposed that a Boulton-Katritzky ring transposition ${ }^{8}$ (similar to that reported by Suzuki et $a l .^{9}$ ) was taking place,
Table 2 Rearrangement of oxazole 4 to isoxazole $\mathbf{6}^{a}$

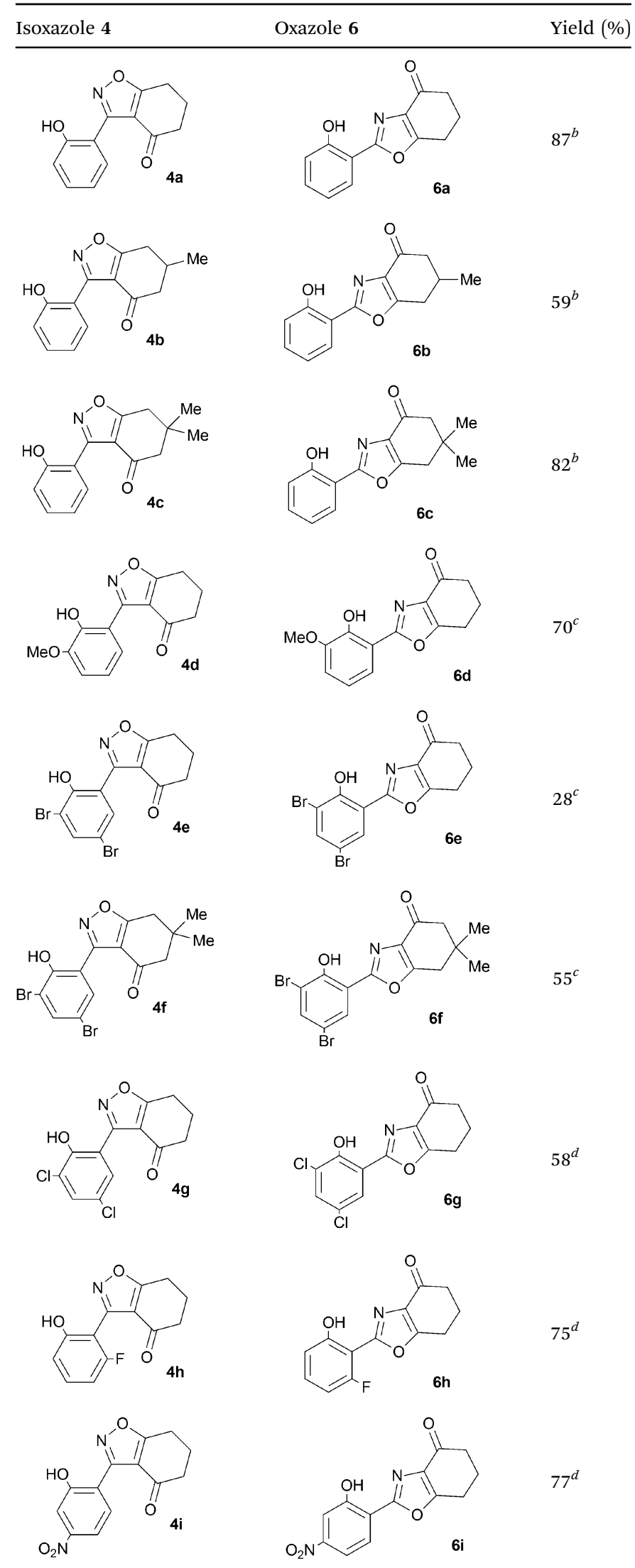

${ }^{a}$ Isoxazole 4 (2.18 mmol), $\mathrm{Cs}_{2} \mathrm{CO}_{3}(4.37 \mathrm{mmol})$, THF at reflux. ${ }^{b}$ Reaction time 4 h. ${ }^{c}$ Reaction time $12 \mathrm{~h} .{ }^{d}$ Reaction time $2 \mathrm{~h}$. 

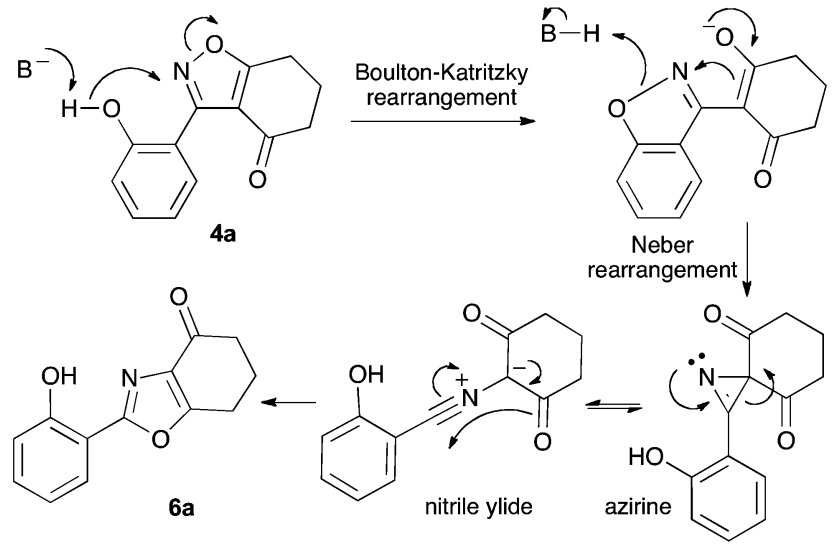

Scheme 3 Proposed mechanism for isoxazole-oxazole rearrangement.

so we retain this as the initial step in this remarkable isoxazoleto-oxazole conversion. ${ }^{10}$ This can be followed by a Neber rearrangement ${ }^{11}$ to give an azirine, thus overall replacing the $\mathrm{N}-\mathrm{O}$ bond of the isoxazole by an $\mathrm{N}-\mathrm{C}$ bond. The azirine may be envisaged to be in equilibrium with a nitrile ylide ${ }^{12}$ stabilised at the formal negative end by the 1,3-dione system, and at the formal positive end by the electron-rich 2-hydroxyphenyl substituent. The 1,3-dipole finally collapses to the oxazole in a $6 \pi$ electrocyclic ring closure.

Previous reports indicate that it is possible to form oxazoles from azirines, and also that an azirine can be generated from an isoxazole either thermally or photolytically. ${ }^{13,14}$ However, the energies required well exceed those of our reaction conditions and thus an alternative rationale was required. The Neber rearrangement is an alternative way of generating azirines given the appropriate leaving group. ${ }^{15}$ This mechanism implies that the base is catalytic, and this was supported by isolation of $\mathbf{6 a}$ (66\%) from $4 a$ using $0.1 \mathrm{~mol}$ equiv. of $\mathrm{Cs}_{2} \mathrm{CO}_{3}$ (THF reflux, $1.5 \mathrm{~h}$ ). An intermediate with $\mathrm{m} / \mathrm{z}$ identical to both the isoxazole and oxazole was observed by LC-MS during the rearrangements of $4 \mathbf{a}$ and $4 \mathbf{c}$ to 6a,c, respectively, and isolated by HPLC. We were not able to unambiguously identify the structure, but NMR studies indicate the cyclohexane portion to be symmetrical, supporting either the azirine or nitrile ylide formulation. ${ }^{16}$ An attempt to crystallise the dimethyl intermediate formed from $\mathbf{4 c}$ led merely to recovery of the oxazole $\mathbf{6 c}$. The oxazole ring opening to form amides $7 \mathbf{a}, \mathbf{b}$ is consistent with nucleophilic attack at C-5 of the oxazole.

To discount the possibility of the oxazoles being formed by retro-cycloaddition from the isoxazoles and recombination via a different connectivity, we have shown that treatment of a
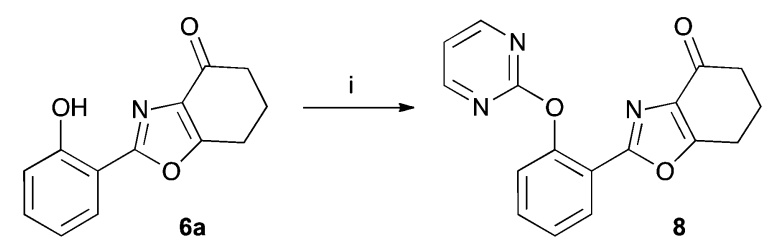

Scheme 4 Reagents: (i), 2-chloropyrimidine, $\mathrm{Cs}_{2} \mathrm{CO}_{3}, \mathrm{Cu}$, dry DMF, 1 day. mixture of the two tetrahydrobenzisoxazoles $\mathbf{4 c}$ and $\mathbf{4 i}$ under the $\mathrm{Cs}_{2} \mathrm{CO}_{3}$-THF reflux conditions led only to the tetrahydrobenzoxazoles $\mathbf{6 c}$ and $\mathbf{6 i}$ predicted by the mechanism of Scheme 3, with no crossover products observed.

The tetrahydrobenzoxazoles prepared herein are closely related to a series of herbicides described in a patent by Ueda et al. ${ }^{17}$ Using benzoxazole 6a we have prepared an example 8 of this group by reaction with 2-chloropyrimidine (47\%) (Scheme 4).

In conclusion, we have discovered an unexpected, remarkably facile novel base-mediated rearrangement of tetrahydrobenzisoxazoles to tetrahydrobenzoxazoles, demonstrated the scope and probed the reaction mechanism of this surprising transformation. The synthetic utility of this rearrangement has been demonstrated by synthesis of a known bioactive compound.

The authors thank Loughborough University for a studentship (A. C.) and Lilly UK for financial support, and ENSIACET (Toulouse) for support for a work placement (R. M.).

\section{Notes and references}

$\ddagger$ Crystal data for 4a: $\mathrm{C}_{13} \mathrm{H}_{11} \mathrm{NO}_{3}, M=229.23$, orthorhombic, Pca2 ${ }_{1}$, $a=15.024(3) \AA, b=21.464(4) \AA, c=13.309(3) \AA, V=4291.8(15) \AA^{3}, Z=16$, $\mu(\mathrm{Mo}-\mathrm{K} \alpha)=0.102 \mathrm{~mm}^{-1}, 36812$ reflections measured, 8811 unique, $R_{\text {int }}=0.064, R_{1}\left[\right.$ for 5081 data with $\left.F^{2}>2 \sigma\left(F^{2}\right)\right]=0.056, \mathrm{w} R_{2}$ (all data) $=$ 0.168 , absolute structure $x=-0.4(19)$. Four molecules in asymmetric unit. For 6b: $\mathrm{C}_{15} \mathrm{H}_{15} \mathrm{NO}_{3}, M=257.28$, orthorhombic, Pna2 ${ }_{1}, a=12.930(2) \AA, b=$ 9.3159(15) ̊, $c=21.663(4) \AA, V=2609.4(8) \AA^{3}, Z=8, \mu(\mathrm{Mo}-\mathrm{K} \alpha)=0.09 \mathrm{~mm}^{-1}$, 25390 reflections measured, 6484 unique, $R_{\text {int }}=0.034, R_{1}[$ for 5459 data with $\left.F^{2}>2 \sigma\left(F^{2}\right)\right]=0.035, \mathrm{w} R_{2}$ (all data) $=0.088$, absolute structure $x=$ 0.2(4). Two molecules in asymmetric unit. CCDC 962972 and 962973.

$\S$ Typical procedure for oxazole formation: 3-(2-hydroxyphenyl)-6,7dihydrobenzo[ $d]$ isoxazol-4(5H)-one $4 a(0.500 \mathrm{~g}, 2.18 \mathrm{mMol})$ and $\mathrm{Cs}_{2} \mathrm{CO}_{3}$ $(1.42 \mathrm{~g}, 4.37 \mathrm{mMol})$ in dry THF $(30.0 \mathrm{~mL})$ was heated under reflux for $4 \mathrm{~h}$. Hydrochloric acid $(2 \mathrm{M} ; 5 \mathrm{~mL})$ and $\mathrm{CH}_{2} \mathrm{Cl}_{2}(25 \mathrm{~mL})$ were added after the reaction mixture had cooled to $20{ }^{\circ} \mathrm{C}$. The mixture was separated and the combined organic layer washed with water $(2 \times 25 \mathrm{~mL})$ and brine $(25 \mathrm{~mL})$. The organic layer was dried $\left(\mathrm{MgSO}_{4}\right)$, filtered and evaporated to dryness under reduced pressure to yield 2-(2-hydroxyphenyl)-6,7-dihydrobenzo[d]oxazol$4(5 H)$-one $6 \mathbf{a}(0.435 \mathrm{~g}, 87 \%)$ as a beige solid, $\mathrm{mp} 202-204{ }^{\circ} \mathrm{C}$ (decomp.); $\nu_{\max }\left(\mathrm{CH}_{2} \mathrm{Cl}_{2}\right) / \mathrm{cm}^{-1} 3804,1694 ; \delta_{\mathrm{H}}\left(400 \mathrm{MHz} ; \mathrm{CDCl}_{3}\right) 2.20-2.27(2 \mathrm{H}, \mathrm{m}$, $\left.\mathrm{CH}_{2}\right), 2.57\left(2 \mathrm{H}, \mathrm{t}, J=5.6, \mathrm{OxCH}_{2}\right), 3.00\left(2 \mathrm{H}, \mathrm{t}, J=6.0, \mathrm{CH}_{2} \mathrm{C}=\mathrm{O}\right), 6.86-6.90$ $(1 \mathrm{H}, \mathrm{m}, \mathrm{Ar}-\mathrm{CH}), 7.10(1 \mathrm{H}, \mathrm{dd}, J=0.8,8.4, \mathrm{Ar}-\mathrm{CH}), 7.30-7.34(1 \mathrm{H}, \mathrm{m}, \mathrm{Ar}-$ $\mathrm{CH}), 7.74(1 \mathrm{H}, \mathrm{dd}, J=1.6,8.0, \mathrm{Ar}-\mathrm{CH}) 10.58(1 \mathrm{H}, \mathrm{br} \mathrm{s}, \mathrm{OH}) ; \delta_{\mathrm{C}}(100 \mathrm{MHz}$; $\left.\mathrm{CDCl}_{3}\right)$ 22.2, $37.9\left(\mathrm{CH}_{2}\right), 110.0(\mathrm{C}), 117.6,119.5,126.3,133.2(\mathrm{Ar}-\mathrm{CH})$, 133.7, 157.7, 161.2, 163.0 (C), 190.7 (C=O). HRMS: $\mathrm{MH}^{+} 230.0809$; $\mathrm{C}_{13} \mathrm{H}_{11} \mathrm{NO}_{3}$ requires $\mathrm{MH}^{+} 229.0812$.

1 3-Acyltetramic acids. For leading references, see: R. C. F. Jones and T. A. Pillainayagam, Synlett, 2004, 2815-2817; R. C. F. Jones, C. C. M. Law and M. R. J. Elsegood, ARKIVOC, 2013, iii, 81-97.

2 3-Acyl-4-hydroxypyridones. For leading references, see: R. C. F. Jones, A. K. Choudhury, J. N. Iley, M. E. Light, G. Loizou and T. A. Pillainayagam, Beilstein J. Org. Chem., 2012, 8, 308-312; R. C. F. Jones, A. K. Choudhury, C. E. Dawson, C. Lumley and V. McKee, ARKIVOC, 2012, vii, 12-24.

3 For a total synthesis, see: K. C. Nicolaou, T. Montagnon, G. Vassilikogiannakis and C. J. N. Mathison, J. Am. Chem. Soc., 2005, 127, 8872-8888.

4 K. E. Wilson, N. N. Tsou, Z. Guan, C. L. Ruby, F. Pelaez, J. Gorrochategui, F. Vicente and H. R. Onishi, Tetrahedron Lett., 2000, 41, 8705-8709.

5 T. Kamigakinai, M. Nakashima and H. Tani, Japanese Pat., JP 10101666 A2, 1998; T. Kamigaichi, M. Nakashima and H. Tani, Japanese Pat., JP 11158109 A2, 1999.

6 J. W. Bode, Y. Hachisu, T. Matsuura and K. Suzuki, Org. Lett., 2003, 5, 391-394.

7 Crystallographic data for amides $7 \mathbf{a}$ and $7 \mathbf{b}$ are deposited at the Cambridge Crystallographic Data Centre, CCDC 962974, 962975 respectively. 
8 For leading references, see: A. Palumbo Piccionello, S. Buscemi, N. Vivona and A. Pace, Org. Lett., 2010, 12, 3491-3493; A. J. Boulton, A. R. Katritzky and A. M. Hamid, J. Chem. Soc. C, 1967, 2005-2007.

9 J. W. Bode, H. Uesuka and K. Suzuki, Org. Lett., 2003, 5, 395-398.

10 Studies with the 3-phenyltetrahydrobenzisoxazole confirm the requirement for the phenolic substituent: unpublished observations.

11 P. W. Neber and A. V. Friedolsheim, Justus Liebigs Ann. Chem., 1926, 449, 109-134. For an application in synthesis, see: N. Garg, D. D. Caspi and B. M. Stoltz, J. Am. Chem. Soc., 2004, 126, 9552-9553.

$12 C f$. S. Lopes, C. M. Nunes, A. Gomez-Zavaglia and T. M. V. D. Pinho de Melo, Tetrahedron, 2011, 67, 7794-7804.

13 See, for example: I. J. Turchi and M. J. S. Dewar, Chem. Rev., 1974, 75, 389-437; K. K. Zhigulev and M. A. Panina, Khim. Geterotsikl. Soedin., 1974, 4, 457-460; M. Maeda and M. Kojima, J. Chem. Soc., Perkin Trans. 1, 1977, 239-247; S. M. Fonseca, H. D. Burrows, C. M. Nunes and T. M. V. D. Pinho de Melo, Chem. Phys. Lett.,
2009, 474, 84-87; C. M. Nunes, I. Reva, T. M. V. D. Pinho de Melo, R. Fausto, T. Solomek and T. Bally, J. Am. Chem. Soc., 2011, 133, 18911-18923.

14 For a base-catalysed isoxazole-oxazole transformation in which the oxazole ring atoms are not all derived from the isoxazole: G. Doleschall and P. Seres, J. Chem. Soc., Perkin Trans. 1, 1988, 1875-1879.

15 A. Padwa, in Comprehensive Heterocyclic Chemistry III, ed. A. R. Katritzky, C. A. Ramsden, E. F. V. Scriven and R. J. K. Taylor, Elsevier, Oxford, 2008, vol. 1, pp. 94-95.

16 Selected spectral data for the intermediate in rearrangement of $\mathbf{4 a}$ to 6a: $\delta_{\mathrm{H}}\left(500 \mathrm{MHz} ; \mathrm{CDCl}_{3}\right) 2.05-2.15\left(\mathrm{~m}, 2 \mathrm{H}, \mathrm{CH}_{2} \mathrm{CH}_{2} \mathrm{CH}_{2}\right), 2.67$ $\left(4 \mathrm{H}, \mathrm{t}, J=6.4,2 \times \mathrm{CH}_{2} \mathrm{CO}\right), 7.30-7.33(1 \mathrm{H}, \mathrm{m}, \mathrm{Ar}-\mathrm{H}), 7.52-7.60$ $(2 \mathrm{H}, \mathrm{m}, 2 \times \mathrm{Ar}-\mathrm{H}), 8.21(1 \mathrm{H}, \mathrm{d}, J=8.2, \mathrm{Ar}-\mathrm{H}), 11.18(\mathrm{~s}, 1 \mathrm{H}, \mathrm{OH})$.

17 A. Ueda, Y. Miyazawa, Y. Hara, M. Koguchi, A. Takahashi and T. Kawana, US Pat., US 6268310 B1, 2001. 